\title{
Strates
}

STRATES Matériaux pour la recherche en sciences sociales

$3 \mid 1988$

Mélanges

\section{Quande les marchands deviennent industriels au Nigéria}

\section{Emmanuel Grégoire}

\section{Q OpenEdition \\ 1 Journals}

Édition électronique

URL : http://journals.openedition.org/strates/311

DOI : 10.4000/strates.311

ISSN : $1777-5442$

Éditeur

Laboratoire Ladyss

Édition imprimée

Date de publication : 1 janvier 1988

ISSN : 0768-8067

Référence électronique

Emmanuel Grégoire, «Quande les marchands deviennent industriels au Nigéria », Strates [En ligne], 3 । 1988, mis en ligne le 08 décembre 2004, consulté le 08 septembre 2020. URL : http://

journals.openedition.org/strates/311 ; DOI : https://doi.org/10.4000/strates.311

Ce document a été généré automatiquement le 8 septembre 2020

Tous droits réservés 


\section{Quande les marchands deviennent industriels au Nigéria}

Emmanuel Grégoire 